\title{
Reflection of the Mystical Element through the Form of Sape' Using Metal in Modern Sculpture
}

\author{
Nor Zafharina Zaluhi, Ramlan Abdullah, Khairi Shamsudin \\ Faculty of Art \& Design, University Technology MARA 40450 Shah Alam, Selangor Malaysia \\ zafharina94@gmail.com, ramlan278@uitm.edu.my, khairi9542@uitm.edu.my \\ Tel of 1st Author: +6 013-8167976
}

\begin{abstract}
The work of art construes the state of the pontoon during the semester to be adjusted by the Sape. He created Sape's current state after awaking from his rest in the vessel. As a result, the arrangement and standing model were created, as well as the Sape' theme. Porpion and engkerabang blossom themes enhance Pua Kumbu. Aims of the study: So that the guidelines and goals are met, they must be stated. They are incorporating a mystical element into Sape's instrument through free-standing sculptures. Create a sculpture using plate metal and a plasma cut machine-a series of freestanding sculptures reflecting mystical elements.
\end{abstract}

Keywords: Forms, Mystical, Sculpture, Sape'

eISSN: 2398-4287 @ 2021. The Authors. Published for AMER ABRA cE-Bs by e-International Publishing House, Ltd., UK. This is an open access article under the CC BYNC-ND license (http://creativecommons.org/licenses/by-nc-nd/4.0/). Peer-review under responsibility of AMER (Association of Malaysian Environment-Behaviour Researchers), ABRA (Association of Behavioural Researchers on Asians) and cE-Bs (Centre for Environment-Behaviour Studies), Faculty of Architecture, Planning \& Surveying, Universiti Teknologi MARA, Malaysia.

DOI https://doi.org/10.21834/ebpj.v6iSl5.2938

\subsection{Introduction}

The Sape was a two-string device. The body was moulded like a Malay decked exchanged perahu with a little inch opening in the middle; thick strings of rattan were twisted and firmly drawn up by tuning-key methods; the sound provided by Schreiber was not entirely different in any case (1896). Fingered, two-stringed guitar; written in 1904 by Shelford. A massive tapang-sculpted instrument. The resonator has been excavated at a 7 to $10 \mathrm{~cm}$; the hole is not closed by the stomach. The resonator's base has a chiselled geometric layout, commonly orchestrated by Kayan on both sides of a pointing edge. The trunk is thick and straight on the head of the winged snake, cut to tell the ruler of the mythic beast (asu). After he woke up in his resting vessel, the angler created a Sape. The design and steady model were created, and the theme of Sape was used. Pua Kumbu's spirit is complemented by the scorpion and generating theme. There are three objectives in this study. These objectives need to be indicated to know whether the guidelines have been followed and the objectives achieved. It is intended by creates a series of standing sculptures that incorporate a mystic element in Sape's instruments. Then create a sculpture with platform metal as a material and a machine cut as a technology-finally, a series of standalone sculptures reflecting mystic elements.

\subsection{Review of Related Literature and Artwork}

When most people hear the word 'Sape,' they envision a guitar-like instrument played by plucking the strings in a rural or communal setting with a unique sound environment. Sape is also known as the Borneo guitar and is a cultural and tourism icon in Sarawak. As

eISSN: 2398-4287 ( 2021. The Authors. Published for AMER ABRA cE-Bs by e-International Publishing House, Ltd., UK. This is an open access article under the CC BYNC-ND license (http://creativecommons.org/licenses/by-nc-nd/4.0/). Peer-review under responsibility of AMER (Association of Malaysian Environment-Behaviour Researchers), ABRA (Association of Behavioural Researchers on Asians) and cE-Bs (Centre for Environment-Behaviour Studies), Faculty of Architecture, Planning \& Surveying, Universiti Teknologi MARA, Malaysia.

DOI https://doi.org/10.21834/ebpj.v6iSI5.2938 
one of Malaysia's top tourist destinations, it is widely used. Patricia Matusky and Tan Sooi Beng (2012) cite the Sape as their primary concern. Sape is not just music; it embodies the legends, spirits, and soul of their ethnicity. Sape's origin and birth are still unknown. Utusan Borneo Sarawak (14 May 2017) believe that Sape is also known for its rituals and spirit. Sape's spirit may have existed in the past, but due to technological advances, it may no longer exist. So long as it is not long-aged hundred or tens year hereditary in possibility family, Sape has a distinct soul that cannot be determined if it the spirit that can possess people who play Sape' so spellbound with Sape oscillation beauty'. The soul intended to love Sape' in terms of his music, oscillation, manufacturing, and cultivate interest in learning to play Sape'.

Some believed that the Sape was a fantasy of a rancher who nodded off in his paddy field cabin after returning from looking for a witch specialist to cure his significant other's infection. According to his fantasy, the rancher was tasked with finding Adau wood from Hill Myna roosting trees. The state of Sape appeared in his dream, and he imagined the soul would come and fix his significant other's disorder. Furthermore, because Sape' originally only had two belts, it may be picked slightly differently than a guitar. Sape can be made from softwoods such as Kayu Pelaik (Kayu Gabus), meranti, tebuloh, or hardwoods such as jackfruit, belian, and others. The harder and more solid the wood used to make Sape', the better the sound it produces. It is a boat. The front surface is levelled, while the back is punctured and not too deep. The thickness of the sides and surface should be uniform to ensure a smooth and clear sound. It used to be made of finely coated rattan or the soft fibres and stems of Enau (ljok), but now the straps are metal guitar strings. For example, wedding, birth, and group celebration music are frequently passed down from one generation to the next. Music lovers have taken note of this melodic instrument's quiet and vivid song. The most recent development in electric Sape' has been made to entice children to play this melodic instrument. Sape' music is now known among local music lovers and traditional music lovers from all over the world. There are two types of Sape': It is used by the witch-specialist (Bali Dayong) to restore order; the player sits on the floor and rises to expel the evil spirits (Udo). The Sape Kanjet is twice the size of the Sape Bali and is used to accompany moves. When the British first came to Sarawak, they brought phone links, which were the first to be used as Sape's strings. Sape is still made in Borneo, and electric Sapes are common. Lan E Tuyang is the leader of the Orang Ulu-Kenyah (Orang Ulu) trio band, which includes two Sapes, a percussionist, and a warrior artist. Sape is a translucent musical instrument that resembles a guitar. It is played by citing and has an elongated body with an open back and a short neck. The Sape varies in length from 1.2 to 1.8 metres, with a width of 20 to $27 \mathrm{~cm}$ and a depth of 9 to $17 \mathrm{~cm}$.

It's made from a tree's neck and body, as well as a single block. Sape is made from aro wood (Cephalomappa spp.). A Sape's body is hollow, with its back open to produce a loud sound. When straps are struck, the buzzing sound is trapped in the empty space or reflected in the open space behind the tape. Some Sape makers act to punch the hole as the index finger on the chest Sape' section to increase the Sape's 'buzzer' sound. In order to improve resonance, a sape player may use one or more of the techniques. Two-thirds of the sound cavity behind the sape's body will be left open, drilled one hole on the surface of the sape and put a guitar pick-up on the surface of the sape', which is close to the sape 'bridge. The ability to play the game with three to eight strings determines a player's skills and tastes. The standard 'Sape' is played by local players. Sape rope is made of various materials. The guitar strap is the most widely used material, followed by the smooth iron cord. Bicycle brake laces have also been used, but infrequently. Some Sape' use nylon straps as Sape' straps. It is made of oil palm or rattan fibre. Social, cultural, and creative values are diverse and unique in this tribal population-for example, pottery, copper, wicker, and jewellery. In addition to wood carvings, Kenyah and Kayan have painted. But each person's decorations, belongings, and possessions, both directly and indirectly, reflect their ethnic status.

In addition to the brightness and subtleties of tonne colour (brightness) of a Sape', the physical instrument of the Sape' instrument can be highlighted. The Sape's favourite part of the day is the dusk (otah). This section contains tasselled carved decorations, pulling carpings, and recurring carvings. Sape's head is often carved with carved sculptures. It appears that the Orang Ulu tribes from Baram and the two Orang Ulu tribes from the region carved Sape' tiles differently (Liew,1962). Borneo Music and Instruments College Borneo Society Journal). These decorations are smaller and only decorate the upper body side of or both sides of the Sape' musical instrument. It shows a well-designed decor by covering the entire front surface of Sape's engraving. The traditional carving of the dog (kalong aso), human (kalong kelunan), and other engravings (kalong) of the Sape' players' interest. In contrast, the head section of a Sape' musical instrument is decorated with a chisel carving, such as the carved chisel (kalong tingang) or the carved dragon (kalong lengunan) depending on the players' level. Human carving (kalong kelunan) for the Maren class only. Players of the ordinary class can decorate the bottom of Sape's surface with carvings such as kalong aso, kalong mata orang, or fern carving (kalong u'ek pako), or round moon motif (kalong beliling bulan) (Matusky, P. (1991). Sarawak instruments. Sarawak Cultural Legacy) Today's meaning and performance requirements no longer serve to cure the patient and celebrate war veterans' return. Sape's music, on the other hand, has been altered solely for fun.

We learn about traditional Malay performers through Mad Annuar Ismail, Rebab Player (1991), Carved Wood. Focus on the two long arms controlling the tall vertical melodic instrument. Man's preoccupation is evident. In artwork, the melodic instrument is controlled by a remote performer's body. The tall, vertical focal structure with cut handles proposes a melodic instrument. To the front is the rebab's "bow." The artist's spine is exposed in the spiky vertical segment. This is a "open structure" model. They exist to elevate an encounter of the spaces within and around the structure. The feeling of growth induced by the performer's employing activity is clearly defined. The stoneworker's use of etch imprints to create rich textural characteristics throughout the structure gives it energy. The dark paint preserves the wood's grain. The model is detachable and does not require a platform. The analyst chooses this craft because of a similar topic, culture, and his use of the instrumental music as his topic. Then, Shia Yih Ying's in Homage to the Vanishing World (1996), Acrylic on canvas, is a celebration of Dayak culture's rich, complex universe. The triptych is made up of three boards. Her work is also full of enchanted authenticity. When she is not doing that, she can be found in the focal board, at the top of the synthesis, as one of the Three Graces. The work's compositional structure is mind-boggling. Astonishingly, she has a deep affinity for her chosen topic. Shia Yih Ying's 
detailed work and presentation style inspired the researcher. Meanwhile, the researcher chose this artwork because of its use of Borneo motif and Dayak culture. Ruzaikha Omar Basaree's painting Siri Dungun - Jendela Terbuka (1978), Acrylic on wood, combines architectural and traditional Malay woodcarving elements. She also expands the definition of "painting" from a two-dimensional surface to three-dimensional work. She also incorporated Islamic aesthetic values into her geometric shapes and arabesque patterns. Her ornaments in her artwork and pattern detail design inspired the researcher. Also, the researcher chose her artwork because it has a similar theme (heritage and culture).

Nature of Roots, Kelvin Chap Kok Leong (1997), a Chinese artist born in Sarawak and based in Kuala Lumpur, uses acrylic on canvas. He was captivated by the Dayak way of life as a child and grew up with many close Dayak friends. He has recently created a series of works of art that feature the lavishness and energy of Sarawak's indigenous Dayak culture. His use of the silkscreen system has allowed him to copy and rehash specific images on the canvas surface, resulting in shocking cadenced effects. In addition to the stencilled images, he adds vibrant colours with brushes. A largely smoothed, firmly compacted accumulation of composite subtleties on canvas that praises one of Southeast Asia's most beautiful and complex inborn cultures. The craftsman's works are notable for their strong climate inspiration and repetitive representative images. The Kenyalang carvings, the entombment houses for the dead, the worshipped hornbill winged creatures, the skulls of executed opponents, the Kenyalang carvings, the entombment houses for the dead, the artist's essence of culture and the researcher's theme inspired the artwork. Furthermore, the researcher chose to celebrate one of Borneo's most colourful and complex tribal cultures. Her theme, motif, and idea inspired my artwork. So, the researcher tries to follow her workflow.

In addition to that, Mastura Abdul Rahman, House of Flower, House of Harmony (1999), Mixed Media and Collage, $183 \mathrm{~cm} \times 276 \mathrm{~cm}$. As with Fatimah Chik, her work reflects new decorative impulses in Malaysian art. She had returned to her Malay "roots" in the 1980s to find her artistic influences. Her paintings, infused with Malay flavour and essentialism, are inspired by Malay-Islamic decorative art impulses. The artwork emphasized the spatial ambience of her interior views of Malay traditional houses. She used Western aerial perspective and foreshortening effects, albeit somewhat metamorphosed by her overt concerns with ornamentation and decorative effects. Like most of her other works, the work depicts the interior of a traditional Malay house from above. Incorporating structural lines and foreshortened shapes from western perspectival influences enhances the work's spatial effect. However, her concerns with surface ornamentation result in a flattened, two-dimensional appearance. She has used traditional Malay shapes and forms such as wooden structural beams. The viewer's eye is constantly drawn to shape and texture. The eye is drawn to the intricately rendered, subdued coloured shapes and patterns on the painting's surface. Her works reflect a strong sense of Malayness. Finally, the House of Flower's Unity in Harmony (1996) is a batik painting and collage by Fatimah Chik, who studied textile design at the ITM School of Art Design and worked in a batik factory in the early 1970s. When she discovered the rich textile traditions of Southeast Asia in the late 1970s, she moved into fine art. One of the more experimental women artists working in the contemporary Malaysian art scene, she attempts to incorporate traditional block printing methods of batik painting and modified regional motifs derived from tribal textiles. Her intricate process of printing blocks, waxing and dying, and being careful. Her highly textured paintings combine painting and craft techniques. In recent years, she has experimented with collage in her batik paintings. As the researcher, this artist uses repetitive shapes and highlights the traditional "tumpal" or "gunung" mountain motif, which is one of her recurring motifs.

\subsection{Methodology}

Sketches and drawings are made based on the data collected for a three-dimensional exploration of the topic. In order to be stored and comprehensive without having to see the actual object, the visual data obtained must be converted into sketches and drawings. The topics are based on Sape's boat form in a dream, the application of flora and fauna in the Pua Kumbu-inspired top body of the Sape and the use of the sape's head as a hornbill inspired by the emblematic bird of Sarawak. Ideation drawings, on the other hand, represent the process of stylization of the subject. The scientist begins her work of art by tracking Sape's present form and the design topic. In a variety of knife heads and a concept of stylization, the researcher attempted to show the sape, the various types of its head. The researcher then examines the form and the size of Sape's genesis. The back of your body is uncovered, and your neck is short. The longitudes of the Sape are, depending on the researcher, between 1.2 and 1.8 metres in length and between 20 and $27 \mathrm{~cm}$ in width. The researcher thus drew the concept according to the original form of Sape. Analytical sketches of Sape with several heads. The researcher's sketch followed the critical session. Sharing ideas with her lectures gave her a fresh idea, and during class discussions, she imagined Sape's new design in a variety of ways. Ideation drawings are the design drawings of the artist and the true form and shape of the process of the Sape. These designs are essential to show how the subject changes and evolves from the beginning of Sape's stylization. However, the final work is not the same as the concepts. This has to do with the production method and the used materials.

\subsection{Result and Finding}

Metal is an important material that the researcher chooses because of its conductivity and the fact that most metals aid in the conduction of electricity and heat, respectively. It's also quite dense. Because of its strong nature and similar characteristics to wood, metal is an excellent choice for this application. Thus, the plasma machine is the device that the researcher employs in order to create a pattern design of Sape's flora and fauna with melt the area that she wishes to dilute in accordance with the pattern of Pua Kumbu. The welding machine that the researcher used to weld her metal plate after cutting the motif of fauna and flora of Sarawak with a plasma machine 
was provided by the university. The researcher used a welding machine to join the metal pieces together, resulting in the stylized shape of Sape when combined with another metal. After welding, grind the metal to maintain the authenticity of the metal's natural colour. As a result, it can be seen that the metal retains its strong characteristic after being ground. The next step involved the researcher determining the appropriate size of the rod to use as a stand for her sculpture. Before you cement the stand, make sure to measure the Sape' that is already in the welding process. After that, weld the stand together to make it stand up. After that, the artwork needs to cement the stand and wait for it to harden completely. In addition, after the cement has hardened, $2 \mathrm{k}$ clear will be poured into an air compressor, which will be used to paint the artwork. When it comes to the cement, the researcher chose it because she wanted to reinforce it, and when it came to the $2 \mathrm{k}$ clear, the researcher chose it because it is a component aerosol clear coat that is easy to apply, flows smoothly, and dries to a long-lasting high gloss finish that can be polished easily with our paint finish products. As a result, it can help to avoid rush production while also preserving the originality of the metal.
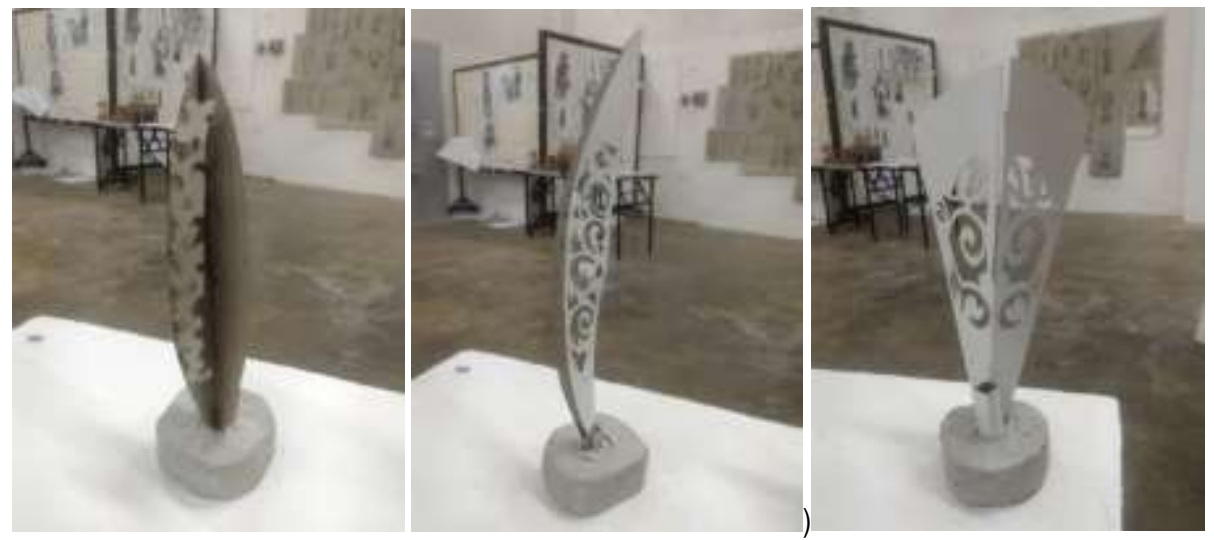

Figure 1: The artwork model is inspired by Sape and expands on flora and fauna (Nor Zafharina Zaluhi, 2019).

Figure 1 depicts a series of mockups of Sape in a stylized concept, as shown in the image above. As a result, the researcher creates it with a different design but with the same content. The researcher is particularly interested in the shape of Sape', which is derived from a boat, as well as the pattern of Sape' derived from flora and fauna of Pua Kumbu. This diagram depicts the steps taken during the creation of an artwork based on the figure above. During the process of creating her artwork, the researcher must complete a few steps. The researcher manages to put in the necessary effort to finish her sculpture in time for her final. Despite the fact that the first attempt had a flaw, the researcher remained calm throughout the process. A series of three artworks, known as Reborn I, Reborn II, and Reborn III, was produced as a result. Using a highly recognizable and sacred artefact, the artist has created a piece of artwork that is inspired by the ceremonial Sape' instrument music that is native to Sarawak and that reinterprets the notions of tradition. This is a subject matter that is very close to my heart. Sape is revered by indigenous people in Sarawak as a source of mystical power. I attempted to construct the shape of Sape', followed by the shape of the boat, in order to stylize a dream that I had realized earlier.

\subsection{Conclusion}

Visual research begins with an investigation and comprehension of the sape character's background and then progresses to idea development based on the analysis of related visual artworks, refinement through model making and material experimentation, and finally fabrication using metals. Briefly stated, to achieve the goal of this artistic investigation, I created a piece of artwork inspired by the shape that improvised around. Most of the artworks demonstrate how the sculpture was created by deriving its shape and body from the movement of sape and highlighting the presence of a mystical element within it. It has been suggested that this artwork be made available to the public or transformed into a functional inquiry due to the suggestion.

\section{Acknowledgements}

The authors would like to acknowledge the Research Management Center (RMC), Universiti Teknologi MARA, for funding under the grants of the 600-IRMI/DANA 5/3/BESTARI (124/2018) for this publication.

\section{References}


Chong, P. L. (1998). Folk Songs of Sarawak: Song from the Kenyah Community. Kuching: Dayak Cultural Foundation Sarawak.

Gayoh, P. (2003). Sape' dan Peranannya Dalam Masyarakat Kayan: Satu Kajian Tentang Peranan Sape' Dalam Masyarakat Kayan Dahulu dan Sekarang. Unpublished Undergraduate thesis, Universiti Malaysia Sarawak.

Gorlinski, V.K. (1989). Some Insights into the Arts of Sape Playing. Sarawak Museum Journal, 39(60):77-104.

Gorlinski, V.K. (1989). The Sampeq of the Kenyah of East Kalimantan, Indonesia: A Case Study of the Recreational Music Tradition. Unpublished M.A Thesis, University of Hawaii.

Jalong, J. (2007). Sape' seni muzik terbilang Orang Ulu Sarawak. Kuching: Massa Kasturi Management. Kedit.

P. M. (1976) Sambe (Sape). In Kumio Koizumi (ed.), Asian Musics in an Asian Perspective.Heibonsha, Tokyo.

Krohn, W.O. (1991)[1927]. In Borneo jungles: among the Dayak headhunters. Singapore: Oxford University Press.

Langub, J. 1997. Tusau Padan, 1933-1996. A Memorial. Borneo Research Bulletin Vol. 28:15-18.

Lim, C. K. N. \& Abdul Rahman, M. F. (2011). Preventing Malaysia's Traditional Music from Disappearing.

SPAFA Journal, The Publication of the SEAMEO Regional Centre for Archeology and Fine Arts. Vol. 21, No.2. 37-47. Bangkok, Thailand: SPAFA. ISSN:0858-1975

Liew, R. (1962). Music and Musical Instruments in Borneo. Journal of the Sabah College Borneo Society 3(10):10-16. MacDonald, M. (1956). Borneo People. London: Jonathan Cape.

Matusky, P. (1991). Musical Instruments of Sarawak. In Sarawak Cultural Legacy, a living tradition. (Chin, L. \& Mashman, V., ed.), pp. 217-230. Kuching: Society Atelier Sarawak.

Myers, C. S. (1914). A Study of Sarawak Music. Sammelbände der Internationalen Musikgesellschaft. 15. Jahrg., H. 2. pp. 296-308

Rutter, O. (1929). The Pagans of North Borneo. London: Hutchinson and Co. Seeler, J. D. (1969). Some Notes on Traditional Dances of Sarawak. Sarawak Museum Journal, 17(34/35):163-201.

Seeler, J. D. (1975). Kenyah dance, Sarawak, Malaysia: a description and analysis. Unpublished MA Thesis, University of Hawaii.

Shelford, R. (1904). Music Instruments. In An Illustrated Catalogue of the Ethnological Collection of the Sarawak Museum. Journal of the Royal Asiatic Society, Straits Branch, 40:1-59.

Tillema, H. (1989)[1938], A Journey among the Peoples of Central Borneo in Word and Picture. Singapore: Oxford University Press. 